Mavi Atlas, 6(1)/2018: 67-89. Araştırma Makalesi | Research Article

Makale Geliș | Received: 09.02.2018

Makale Kabul | Accepted: 15.03.2018

DOI: 10.18795 /gumusmaviatlas.418510

Muammer AK

Dr. Öğr. Üyesi

Gümüşhane Üniversitesi, Sağlık Bilimleri Fakültesi, Gümüşhane-Türkiye Gümüşhane University, Faculty of Health Sciences, Gümüşhane-Turkey ORCID: 0000-0003-0241-1893 akmuammer@hotmail.com

\title{
Üniversite Gençliğinin Kimlik ve Siyaset Algısı: Gümüşhane Üniversitesi Örneği
}

$\ddot{O} \mathbf{z}$

Bu çalışmada üniversitede okuyan öğrencilerin kimlik ve siyaset algıları ölçülmüștür. Araştırmaya katılanların \%54,2'si kadın, \%45,8'i erkektir. Araştırma kapsamında Gümüşhane Üniversitesi’nde farklı bölüm ve sınıflarda okuyan öğrenciler arasından basit tesadüfü örneklem yöntemi kullanılarak belirlenen 233 öğrenciye anket uygulanmıştır. Araştırmanın saha çalışması Aralık 2017'de yapılmışıı. Araştırma tarama modeline uygun şekilde tasarlanmıştır. Araştırmanın amacı, üniversite öğrencilerinin kimlik ve siyaset algılarını tespit etmektir. Bu bağlamda araştırma, üniversite öğrencilerinin kimlik ve siyaset algıları nasıldır?, siyasete katılım düzeyleri nedir?, siyasi-dini-ideolojik olarak ve modern-geleneksel düzlemde hangi kimlikleri kendisine uygun görüyorlar?, vatandaşlı̆̆ı nasıl tanımlıyorlar? gibi soruların cevaplarını aramaktadır. Araştırmanın sonuçlarından bazıları şöyledir: Katılımcıların çok yüksek bir oranı $(\% 88,5)$, modern-gelenek düzleminde, kendilerini biraz modern biraz geleneksel olarak görmektedir. Katılımcıların önemsedikleri ve önceledikleri üç toplumsal aidiyetin/kimliğin Müslüman gibi dini, Türkiye Cumhuriyeti vatandaşı gibi siyasi ve Türk gibi etnik/siyasi aidiyetler olduğu görülmektedir. Araştırmanın bir başka sonucu ise, katılımcıların siyasal katılımlarının daha çok seçimlerde oy verme şeklinde olduğudur. Ayrıca, katılımcıların sivil toplum örgütlerine katılım düzeyi çok düşüktür. Yine katılımcılara göre, Türkiye Cumhuriyeti vatandaşı olmak için, hukuki statü yeterlidir; ancak bir kişinin Türkiye'nin Cumhurbaşkanı olması için ise Müslüman olması gerekmektedir. Araştırma sonuçlarına göre, Türkiye'nin en önemli sorunları arasında öne çıkan ilk üç sorun sırasıyla; terör, adaletsizlik ve eğitim olduğu görülmektedir.

Anahtar Kelimeler: Kimlik, Siyaset, Vatandaşlık, Üniversite, Gençlik.

\section{Identity and Politics of University Youth: Gümüşhane University Sample}

\begin{abstract}
In this study, the identity and political perceptions of the students studying at university are measured. $54.2 \%$ of the participants were female and $45.8 \%$ were male. Within this research from the University of Gumushane students studying in different sections and classes using a simple coincidence sampling method was applied to 233 students in the survey. The fieldwork of the research was carried out in December 2017. The research was designed in accordance with the screening model. The aim of this study is to determine the identity and political perceptions of university students. In this context, how is the identity and political perceptions of university students?, What are the levels of political participation?, What identities do they see fit politically, religiously, ideologically and on a modern-traditional level?, How do they define citizenship? are looking for answers to such questions. Some of the results of the survey are as follows: A very high proportion of participants $(88.5 \%)$ regard themselves as somewhat modern and somewhat traditional on the modern-tradition level. They care about the participants and they preceded the three social belonging / religious identity as Muslims, citizens of the Republic of Turkey as well as political and ethnic Turks as / is observed that political affiliations. Another consequence of the survey is that the political participation of the participants is more like voting in the elections. In addition, the level of participation of NGOs in civil society organizations is very low. According to the participants, to be citizens of the Republic of Turkey, it is sufficient legal status; but for a person to become Turkey's president must be a Muslim. According to the survey, Turkey's most important outstanding issue between the top three issues respectively; terror, injustice and education.
\end{abstract}

Keywords: Identity, Politics, Citizenship, University, Youth. 


\section{Giriş}

Türkiye'de kimlik ve siyaset konuları Türkiye'nin Batılılaşma veya çağdaşlaşması ile ilgili olan konulardır. Bu bağlamda, konunun daha iyi anlaşılması için Türkiye'nin bu süreciyle ilgili kısa bilginin verilmesinin faydalı olacağı düşüncesindeyiz. Türkiye, Tanzimat'la başlayan ve günümüzde de devam eden ve Batılılaşmak, çağdaşlaşmak, modernleşmek olarak kavramsallaştırılan bir topyekûn değişmeyi kendine ideal olarak belirlemiştir. $\mathrm{Bu}$ değişimin öznesi devlet, nesnesi ise toplumun tüm fertleridir. $\mathrm{Bu}$ değişim sürecinde, hukuk, siyaset, ekonomi ve eğitim değişimin temel araçları olmuştur. Yaşanan bu değişim veya inşa süreci 1980'lerden sonra küreselleşme olarak kavramsallaştırılan yeni bir boyut kazanmıştır. Bu küreselleşme süreci, bazı batı ülkelerinde ve $A B D$ 'de üretilen kültür endüstrisi ürünlerinin tüm dünyayı istilasıyla gerçekleşen bir benzeşim sürecidir. Bu bağlamda modernlik, bu benzeşmenin muhtevası ve biçimi olarak anlam kazanmaktadır. Fertler ve toplumlar, küresel kültürün nesnesi oldukça, daha çok modernleştiklerini düşünmektedir. İsimlendirme ister Batılılaşma ister küreselleşme olsun, her iki durumu da tanımlayan en temel kavram, modern olmaktır. Bu bağlamda modernlik, Türkiye'nin hem batılılaşma hem küreselleşme sürecinde hem de günümüz Türkiye'sinde olması gereken olarak sunulmakta ve gösterilmektedir (SEKAM, 2013:22). Batılılaşma veya küreselleşme sürecinde ülkelerin aydınlarına önemli görevler düşmektedir. Ancak, batılılaşma sürecinde bulunan toplumlarda, aydınlar arasında en yaygın zihniyet durumunun, modernleşme/batılılaşma arasındaki farklılaşmayı kavrayacak bir düzeyde olmamasıdır. Böylece modernleşme anlayışı, batının bilinen örneklerinin kabaca taklit edilmesinden ibaret kalır. Batıda modernleşmeyi hazırlayan süreçler, rasyonelleşme, üretimde işbölümü ve endüstrileşme, idari yapıda bürokratikleşme ve inanç alanında sekülarizasyon gibi hususları kapsadığını görürüz. Modernleşmeyi böyle alınca mesele, batıyı taklit etme zorunluluğundan uzaklaşıp yeni bir tarihsel/toplumsal formasyonun oluşması haline gelmektedir. Böyle bir tarihsel kategoriye yönelecek politikalar, bir anlamda modernleşme politikaları olarak karşımıza çıkmaktadır. Türk modernleşmesinin, batı karşısında büyük bir imparatorluk kaybetmiş veya kaybetmekte olan aydın/yönetici 
zümrenin yaşadığı büyük şokla gelen batılılaşma etkisinden kurtulması, çok zor ilerleyen bir süreç olmuştur (Bilgin, 2007:133-134).

Kemal H. Karpat'a (2009:240) göre, modern Türkiye'de hâkim güç haline gelen modernite, Batı dünyasına yetişme, başka bir değişle giyim-kuşam, düşünce ve yaşam tarzı açısından Batılı insanlara benzeme hareketi olarak anlaşıldı. Ancak, modernitenin yüzeyselmiş gibi görünen hedeflerinin ardında, bağımsız bir Osmanlı, daha sonra da Türk devletini sürdürmek şeklinde daha derin bir arzu vardı. Bunun toplumun kimliğini, kültürünü ve inancını koruyacağı varsayılıyordu, ne var ki devlet kendi bekasıyla o kadar meşguldü ki, modernite yürüyüşünü engelleyeceği varsayımıyla, toplumun tarihini ve sosyokültürel özelliklerini bu uğurda feda etmekten çekinmedi. Modernliğe giden yol olarak seçilen laiklik, git gide devletin kendisine yöneltilen eleştirilere modernliğin ve çağdaş uygarlığın yadsınması damgasını vurarak, kendini meşrulaştırmasının ve haklı çıkarmasının bir aracı haline geldi. Halkın geneli için modernleşme arzusu, laikliğin öngördüğü gibi, toplumun kimliğini, kültürünü ve her tür geleneğini değiştirmesini gerektirmiyordu. Sıradan Müslümanlar için modernlik, daha ziyade, ekonomik gelişme, daha iyi bir haberleşme sistemi ve daha etkili bir yönetim tarzı demekti. Bu bağlamda değişme, bir toplumun hayatında önemli yeri olan sınıfların ve genel olarak halkın değişikliği istemesi, onu itmesi, onu yürütmesi işi haline gelmedikçe o değişme toplumu daha iyiye değil, belki daha kötüye götürür. Değiş̧meyi zoraki, israflı ve yüzeyde kalmış bir biçime sokar. Türk tarihinde modern reform fikrinin doğuşu zamanından sonra Türkiye'de durum hep böyle olmuştur (Berkes, 2016:19).

Fuat Keyman'a (2004:129) göre, 1980'den bu yana Türkiye, hem küreselleşme sürecinin etkisi hem de Türk modernleşmesinin yaşadığı dönüşümlerin sonucunda ekonomik, kültürel ve siyasal yaşam alanlarında ciddi bir değişim ve dönüşüm geçirmektedir. Kültürel ve siyasal alandaki bu gelişmeler, dinsel, etnik ve cinsel farklılığa dayalı kimlik siyasetinin ve tanınma taleplerinin güçlenmesiyle, sivil toplumun canlanması, sivil toplum örgütlerinin önem kazanmasıyla, bireysel, siyasal, ekonomik ve sivil hakların korunmasını ve genişletilmesini isteyen vatandaşlık 
taleplerinin kamusal alana taşınmasıyla bağlantılı bir gelişme olarak karşımıza çıkmaktadır. Tüm bu gelişmeler, artık Türk modernleşmesinin ve siyasetinin kültürel kimlik siyasetinden bağımsız düşünülemeyeceğini çok açık bir biçimde ortaya koydu. $\mathrm{Bu}$ bağlamda, kültürel kimlik siyasetleri Türkiye'de siyasetin en önemli referanslarından birisi konumuna yükseldi. Ama bu süreç içinde, sosyal demokrasi toplumsal yaşamın bu değişim ve dönüşümüne kendisini eklemleyemedi. Ortaya çıkan yeni ekonomik aktörlere, kimlik hareketlerine ve vatandaşlık taleplerine sosyal demokratik bir anlam verecek söylemsel ve siyasi stratejiler üretemedi. Daha da önemlisi, giderek toplumdan uzak ve devlet-merkezci bir siyaset anlayışına büründü. Ayrıca, Türk modernleşmesi, Türkiye'deki geniş toplum kesimlerinin 16. yüzyıldan başlayarak giderek bozulan ekonomik ve siyasal konumlarında olumlu bir değişim yaratamadığı gibi, Türk modernleşmesinin böyle bir çabası da olmamıştır (Topses, 2017:1871). Türkiye, özellikle 1970’li yıllarda yoğunlaşan toplumsal değişim sorunlarını siyaseten karşılayacak politikalar üretememiştir. Bunun en önemli sebeplerinden birisi, hâkim resmi elitin söz konusu toplumsal dönüşümü kavrayacak zihni donanımdan mahrum olmasıdır (Bilgin, 2007:98).

Kemal H. Karpat'a (2017: 57) göre, kimlik, milli devletin ortaya çıkması ile güncel bir önem kazanmıştır. Bu kimlik yeni olduğu kadar, şüphesiz en çok tartışma yaratan konulardan biridir ve hakkında fikir birliği yoktur. Her ülkenin kavim, millet, sosyal sınıf, tarihi-sosyal ve kültürel yapısına göre şekil ve yapı özellikleri gösteren kimlik meselesi Türkiye için diğer ülkelere kıyasla çok farklı özellikler arz etmektedir. Türkiye'nin modernleşmesi bir bakıma Batı'yı model alarak yürütüldüğü için, kimlik meseleleri de Batı modelinin kavramsal ve metodolojik sınırları içinde ele alınmaktadır. Hâlbuki Türkiye'nin kimlik meseleleri hem çok geniş tarihi bir çerçeve içinde hem de Türk-Osmanlı toplumunun yapısı ve kimlik değişmeleri göz önünde tutularak incelenmelidir.

Kimlik ve kültür arasındaki ilişkiler, sıklıkla kültürel kimlik kavramıyla betimlenir. Kültürel kimliğin içeriğini oluşturan temel bağlam, "biz" duygusunun topluluk içerisinde yarattığı kolektif bilinçtir. Kültürel kimlik, fertleri aşan sosyal bir 
boyuta sahiptir. Sosyal bir varlık olarak kabul edilen insanın, farklı özellikleriyle oluşmuş insan toplulukları içerisinde yaşayabilmesi, topluluğu fertte temsil ettirir hale getirmiştir. Böylece fark edilir ki; kültürel kimlik, "ben kimim” den çok "biz kimiz" sorularına denk düşmektedir. Kültürel kimlik, bir kültüre katılımın bilince çıkarılması ya da o kültüre ait olduğunun ilan edilmesidir. Kültürel kimlik, tek tek bireyleri "biz" duygusunda birleştiren bir kimlik duygusudur (Erkal vd, 1997:398). Bilgin (2007:26) kimliği, bir kişi veya grubun kendisini tanımlaması ve kendini diğer kişi veya gruplar arasında konumlandırması olarak tanımlar. Kimlik ihtiyacı bazı boyutlarında diğer insanlara benzemeyi, bazı boyutlarında ise onlardan farklılaşmayı gerektirmektedir. Dolayısıyla kimlik kavramı, benzerlik ve farklılık kutupları arasında diyalektik bir tarzda kendini göstermektedir.

Şerif Mardin'e (2017:112) göre, çağdaş sosyal bilimler arasında kimlik konusunun ele alınma tarzında bir değişim olmuştur. İnsanların, kendi hayatları boyunca tatmin edici bir benlik oluşturma çabalarını inceleyen yaklaşımın yerini kimliği bir grubun bir cemaatle başarılı biçimde bütünleşme sürecini ifade etmek üzere kullanan çalışmalar almıştır. Bu bağlamda kimlik, insanların ait oldukları ve uyum sağlamaya çalıştıkları sosyal ağ kümelerine göre değerlendirilmektedir. Kimlik olgusu, kültürel yaşam alanı içinde, farklı düzeylerde ve bağlamlarda, son yıllarda çok önemli etkiler yaratmış ve merkezi bir sorun olarak karşınıza çıkmıştır. Keyman'a (2009:52) göre, kimlik olgusunun birey/grup hak ve özgürlüklerden toplumsal benlikle ilgili ahlaki norm ve etik kodlara, bireysel yaşam tarzı tercihlerinden kitlesel tüketim kalıplarına, popüler kültürden yüksek kültüre kadar, geniş alanda ve mikro düzeyde günlük yaşam pratikleri içinde, makro düzeyde ise devlet toplum/birey ilişkilerinin düzenlenmesinde, simgesel ve toplumsal sermayenin giderek artan rolü ve önemi içinde kültürel yaşam alanı bağlamında sistem kurucu ve sistem dönüştürücü bir etkisi olmuştur.

Kongar'a (2000:53) göre, çağdaş devlet, kendi vatandaşları arasında din, mezhep, 1rk, milliyet, cinsiyet, yaş, coğrafya, kültür ve siyasal parti ayrımı yapmadan, kendisine vatandaşlık bağı ile bağlı herkese eşit davranan, varlığını, vatandaşlarına sağladığı başta güvenlik olmak kaydı ile sağlık, eğitim ve benzeri hizmetlerle meşru kılan bir 
örgütlenmedir. Foucault modern devleti, bireylere rağmen, onların kim olduğuna aldırmadan, hatta varlıklarını bile yok sayan bir kendilik olarak değil; tam tersine bu bireyselliğe yeni bir biçim tayin etmeleri ve belirli bir düzenekler toplamına tabi tutmaları koşuluyla bireylerin onunla bütünleşebildikleri gelişkin bir yapı olarak düşünmek gerektiğine inanmaktadır (Bayart,1999:140). Drake'e (2016:71) göre, sosyal kimlikler empoze edilebilir ve aynı zamanda sahiplenilebilir, düzeltilebilir ve yeniden görüşülebilir. Yazara göre, sosyal kimlik asla basit bir şekilde belli veya bilinen olamaz. $\mathrm{Bu}$ yüzden o siyasi bir sonuç olarak görülmelidir; çünkü kimlikler siyasaldır. Kimliğimizi tanımladığımız terimlerle, kendimizin ve başkalarının gözünden kendimiz için toplumsal kategoriler üretiriz. Bunun gerçekleşmesi için de toplumsal kimlikler fark edilmiş olmalı ve en azından diğerlerini tanımlayan iktidar tarafından kabul edilen kodlar içermelidir. Kendimiz bir toplumsal kimlik üretemez ve onunla tanımlanmayı bekleyemeyiz. Sosyal kimlikler, kişisel ya da öz- kimlikten ayırt edilebilir, ancak bu analitik kategoriler tamamen ayrılamaz. Sosyal kimlikler bir grup tarafından paylaşılır.

Genç nüfus, Türkiye'deki nüfusun önemli bir kısmını oluştursa da gençlerle ilgili araştırma sayısı, bunun sonucunda mevcut veriler ile bu verilerin çeşitliliği, derinliği ve güncelliği çok kısıtlıdır. Bu durum, Türkiye'de gençlerle ilgili araştırmalarda ve raporlarda kaynak olarak yararlanmak üzere, özellikle Avrupa temelli yayınlara başvurmak yoluyla bertaraf edilmeye çalışılmaktadır (Onuncu Kalkınma Planı, 2015:17). Bu araştırmanın yapılmasındaki temel saik bu husus olup, araştırmanın bu konuya mütevazı bir katkı sağlayacağı düşünülmektedir. Araştırmanın amacı, üniversite öğrencilerinin kimlik ve siyaset algılarını tespit etmektir. Bu bağlamda araştırmanın temel problemini, “üniversite öğrencilerinin kimlik ve siyaset algıları nasıldır?”sorusu oluşturmaktadır. Yine araştırmada, üniversite öğrencilerinin siyasete katılım düzeyleri nedir?, siyasi-dini-ideolojik olarak hangi kimlikleri kendisine uygun görüyorlar?, vatandaşlığı nasıl tanımlıyorlar? gibi soruların da cevapları aranmaktadır. Ayrıca araştırma ile üniversiteli gençlerin kendilerini gelenek-modern ekseninde nasıl konumlandırdıkları da tespit edilmiştir. Bu konumlanışın biçim ve miktarını belirlemek önemlidir. Çünkü gelenek-modern farklılığı/karşıtlı̆̆ 1 , yukarıda da ifade edildiği üzere, 
bireysel ve toplumsal tüm alanlarda birbirinden çok farklı ve hatta çoğu zaman karşıt bir tutum ve tavır, ilgi ve istek düzeylerini, daha da önemlisi, değerler sistemini ve yaşayış tarzını gerektirmektedir. Gençlerin kendilerini gelenek-modern ekseninde nasıl konumlandırdıkları tespit edilirse, gençlerimizin kendilerine şu veya bu şekilde sunulan veya dayatılan modernliği ne düzeyde kabullendiklerini tespit etmek mümkün olabilecektir.

\section{Üniversite Öğrencilerinin Kimlik ve Siyaset Algısı Araştırması}

\section{Yöntem}

$\mathrm{Bu}$ çalışma üniversite öğrencilerin vatandaşlık algılarını ölçmeye yönelik uygulamalı bir araştırmadır. Araştırma kapsamında, Gümüşhane Üniversitesi’nde farklı bölüm ve sınıflarda okuyan öğrenciler arasından basit tesadüfü örneklem yöntemi kullanılarak belirlenen 233 öğrenciye anket uygulanmıştır. Araştırmanın saha çalışması Aralık 2017'de yapılmıştır. Araştırma tarama modeline uygun şekilde tasarlanmıştır. Araştırma için öncelikle ilgili literatür taraması yapılmış, daha sonra benzer araştırmalardan yararlanılarak anket soruları oluşturulmuştur. Özellikle KONDA'nın yaptığı "Vatandaşlık Araştırması 2016'dan" ve 2013 yılında SEKAM'ın yaptığı “Türkiye Gençlik Raporu” araştırmasından yararlanılmıştır. Veriler bilgisayar ortamına aktarıldıktan sonra, SPSS 16.0 paket programı ile analizler yapılmıştır.

\section{Demografik Özellikler}

Araştırmaya katılanların \%52,8'i (123) kadın, \%47,2'si (110) erkektir. Yaş dağılımı ise şöyledir: \%2,6'sı 16-18 yaş, \%62,7'si 19-21 yaş, \%31,8'i 22-24 yaş, \%1,7'si 25-27 yaş, \%1,3'ü 28 ve üstü yaş grubundadır. Adrese Dayalı Nüfus Kayıt Sistemi (ADNKS) sonuçlarına göre; Türkiye toplam nüfusu 2016 yılı sonu itibariyle 79 milyon 814 bin 871 iken 15-24 yaş grubundaki genç nüfus 12 milyon 989 bin 42 oldu. Genç nüfus, toplam nüfusun \%16,3'ünü oluşturdu. Genç nüfusun, \%51,2'sini genç erkek nüfus, \%48,8'ini ise genç kadın nüfus oluşturdu (TÜİK, 2017a). 
Katılımcıların \%18'i birinci sınıfta, \%29,5'i ikinci sınıfta, \%32,2'si üçüncü sınıfta, \%19,7'si dördüncü sınıfta okumaktadır. TÜİK verilerine göre, lise ve dengi okul mezunu olan 25 ve daha yukarı yaştakilerin toplam nüfus içindeki oranı \%19,5 iken bu oran erkeklerde \%23,5, kadınlarda \%15,6'dır. Yüksekokul veya fakülte mezunu olan toplam nüfus oranı \%15,5 olup bu oran erkeklerde \%17,9 kadınlarda ise \%13,1'dir (TÜİK, 2017b).

Katılımcılar aile aylık geliri bakımından incelendiğinde \%7,7'si 700 tl ve altı, \%18,5'i 701-1200tl aras1, \%29,2'si 1201-2000tl aras1, \%21'i 2001-3000tl aras1, \%14,6's1 3001-5000tl aras1, \%9'u 5001tl ve üstü gelire sahip olduğu görülür. Katılımcıların aylık eline geçen para miktarının \%9,4'ünün 0-300t1, \%33,5'inin 301500tl, \%30,9'unun 501-75tl, \%16,3'ünün 751-1000tl, \%8,6'sinin 1001-2000tl, \%1,3'ünün 2001 ve üstü olduğu görülmektedir. Katılımcılar hayatın büyük kısmının geçirildiği yer itibariyle incelendiğinde \%18'i köy-kasaba, \%24,5'i ilçe, \%57'si şehir, \%0,5'i yurt dışında yaşayan kişiler olduğu belirlenmiştir. Bu verilere göre, öğrencilerin genellikle alt ve orta gelir grubunda olan ailelerin çocukları olduğu ve çok büyük bir çoğunluğun $(\% 81,5)$ şehirde (il veya ilçe) yaşadıkları anlaşılmaktadır.

\section{Bulgular ve Yorum}

\section{Kimlik ve Aidiyet}

Araştırma kapsamında dikkate alınan temel konulardan biri, üniversite öğrencilerinin ferdi kimliklerinin ve toplumsal aidiyetlerinin hangi noktada ve düzeyde gerçekleştiği ve ayrıca bunların ne gibi işlevler üstlendiğiyle ilgilidir. Şerif Mardin'e göre (2017:112), çağdaş sosyal bilimler arasında kimlik konusunun ele alınma tarzında bir değişim olmuştur. İnsanların, kendi hayatları boyunca tatmin edici bir benlik oluşturma çabalarını inceleyen yaklaşımın yerini kimliği bir grubun bir cemaatle başarılı biçimde bütünleşme sürecini ifade etmek üzere kullanan çalışmalar almıştır. $\mathrm{Bu}$ bağlamda kimlik, insanların ait oldukları ve uyum sağlamaya çalıştıkları sosyal ağ kümelerine göre değerlendirilmektedir. 


\section{Modern-Gelenek Düzleminde Kimlikler}

Halil İnalcık'a (2017:185) göre, örf, adet ve gelenek; bir halkın yaşamını biçimlendiren, onun doğa ve toplum içinde davranış biçimlerini belirleyen bir sosyopsikolojik mekanizmadır. Körü körüne ona uyarsınız, uymak zorundasınız. Örf adet kuşkusuz değişir ama bu değişmeyle yeniden vücuda gelen şey, eskisiyle yenisinin kaynaşmış yeni bir terkibidir. Bu bağlamda, geleneksel-modern düzlemde yeni kimlik terkibinin "biraz modern biraz geleneksek" olduğu ifade edilebilir.

Araştırma kapsamında öğrencilerin modern- geleneksel düzlemde kimliklerini nasıl tanımladıkları tespit edilmiş olup bununla ilgili veriler tablo 1'de verilmiştir.

\begin{tabular}{|l|l|l|l|l|}
\hline Kimlikler & $\begin{array}{l}\text { Cok uygun } \\
(\%)\end{array}$ & Uygun (\%) & $\begin{array}{l}\text { Uygun değil } \\
(\%)\end{array}$ & $\begin{array}{l}\text { Hiç uygun } \\
\text { değil (\%) }\end{array}$ \\
\hline Biraz modern biraz geleneksel & 39,1 & 49,4 & 10,4 & 0,9 \\
\hline Modern & 32,2 & 53,2 & 7,3 & 7,3 \\
\hline Geleneksel & 18 & 54,1 & 20,6 & 7,3 \\
\hline
\end{tabular}

Tablo 1: Katılımcıların Modern-Gelenek Düzleminde Kendilerini Tanımlayışları

Tablo 1'e göre katılımcıların, \%88,5 (çok uygun+uygun) gibi çok büyük bir oran1 biraz modern biraz geleneksel, \%85,4'ü modern ve \%72,1'i geleneksel kimliği kendisine uygun veya çok uygun olarak gördüğü anlaşılmaktadır. Bu sonuçlar SEKAM'ın araştırmasına göre farklılık göstermektedir. Araştırmaya göre, katılımcıların $\% 72$ kendisini biraz modern biraz geleneksel, \%12 modern ve \%16 ise geleneksel olarak ifade etmiştir (SEKAM, 2013:23). Ancak iki araştırmada da biraz modern biraz geleneksel kimliğini ilk sırada olduğu görülmektedir. Buna göre üniversite öğrencilerinin Türkiye'nin genel genç kitlesiyle benzerlik gösterdiği, geleneksel-modern düzlemde melez bir kimliğe sahip olduklarını ifade edebiliriz.

\section{Öğrencilerin Genel Toplumsal Aidiyetleri/Kimlikleri}

Gençlik yılları, hemen herkesin ferdî kimliğinin ve toplumsal aidiyetinin oluşmasının da ötesinde kimliğinin/aidiyetinin berraklaşıp netleştiği bir dönem olarak 
anlam kazanmaktadır. Fertler bu dönemde edindikleri/inşa edilen kimliklerine ve aidiyetlerine göre, benzerleriyle iş ve eylemlerde, tutum ve tavırlarda bir araya gelir ve ötekilerden ayrışırlar. Birleşme ve ayrışma ise; hayat tarzında, dinî, ahlâkî, siyasî ve kültürel değerlerde kendini olanca biçimiyle açığa vurur. SEKAM'ın Türkiye Gençlik Araştırmas1, gençlerin gerek modern-geleneksel düzleminde ve gerekse dinî, siyasî ve ideolojik kimlikler açısından kendilerini konumlandırışlarının büyük oranda melez bir duruma işaret ettiğini, sahiplenilen konum veya kimliklerin büyük oranda isimsel (sloganlaşmış) olduğunu göstermiştir (SEKAM, 2016: 27-28).

Kendinizi daha çok ne olarak hissediyorsunuz? sorusuna katılımcıların \%28,7'si Müslüman, \%25,3'ü Türk, \%6,8'i Kürt, \%27'si T.C. vatandaşı, \%6,4'ü Alevi ve \%5,8’i ise diğer cevabını vermiştir. Buna göre katılımcıların önemsedikleri ve önceledikleri üç aidiyetin Müslüman gibi dini, T.C. vatandaşı gibi siyasi ve Türk gibi etnik/siyasi aidiyetler olduğu görülmektedir. Ayrıca katılımcılara, hayat tarzı bakımından kendinizi nasıl görüyorsunuz? sorusuna \%31,3'ü modern, \%54,1'i geleneksel muhafazakâr, \%16,4'ü dindar muhafazakâr cevabını vermiştir. Buna göre öne çıkan kimlik/aidiyet; toplumsal aidiyet/kimlik düzleminde, Müslüman, T.C. vatandaşı ve Türk; hayat tarzı düzleminde, geleneksel muhafazakâr; modern-gelenek düzleminde ise biraz modern biraz gelenekseldir. Bu sonuç yapılan diğer araştırmalarla benzerlik göstermektedir (SEKAM,2013: 25). Buna göre, Türk ile Müslüman kimlikleri arasında bir kapsam ilişkisi olduğu düşüncesiyle bunu tespit etmek için sorunun seçenekleri arasında "Türk, Müslüman ve Türk-Müslüman" ifadelerinin bulunması gerekirdi. Bu araştırmada sorunun seçeneklerinde bu bulunmadığı için Türk-Müslüman arasındaki kapsam ilişkisini tespit edemiyoruz. Bundan sonraki yapılacak araştırmalarda bu sorunun seçeneklerinde bu ifadenin bulunması bu ilişkinin tespitine imkân verebilir. Biri dini (Müslüman), diğeri etnik/siyasi veya kültürel (Türk) kimlik olması hasebiyle genelde araştırmalarda, iki farklı kimliğin birleştirilmesi olacağı için, sorunun seçeneklerinde ayrı ayrı yazılmaktadır. Ancak tarihi tecrübe bize bu iki kimliğin iç içe geçtiğini göstermektedir. Balkan ve Kafkasya göçleri bunun en güzel örnekleridir. İlber Ortaylı’ya (2006: 33) göre, Osmanlı kimliği, Türklüğün ağır bastığı bir Müslümanlıktır. 
Öbür Müslüman etnik gruplar bu Türklüğe dil olarak intibak ettikleri ölçüde Osmanl1Türk olmaktadırlar. Genel kural, Türk olmayan ana babanın Türkçe konuşup anlaşmaları ve çocuklarının da bu dili izlemeleri ölçüsünde ailenin Türk olacağıdır. Dolayısıyla son yüzyılın Osmanlılı̆ğ, Türk kimliğine kolayca dönüşmektedir. İsmail Kara’ya (2010:191) göre, Türk ve Müslüman kelimeleri birbirinin yerine rahatlıkla kullanılabilecek kelimeler hatta kavramlar olduklarından "Müslüman olmayan Türk" halkın nazarında anlamlı, anlaşılabilir bir ifade değildir. Din ile devlet arasındaki zorunlu denebilecek ilişski bu aşamada milleti de içine alacak şekilde genişlemektedir.

Dindarlık açısından kendinizi nasıl tarif edersiniz? sorusuna, \%5,2'si “dinin gereklerine pek inanmayan”, \%46,4'ü “inançlı ama dinin gereklerini pek yerine getirmeyen”, \%47,2'si “dinin gereklerini yerine getirmeye çalışan dindar biri”, \%1,3’ü “dinin tüm gereklerini tam yerine getiren dindar" cevabını vermiştir. Türkiye'de 2011 yılında 1538 kişi üzerinde yapılan araştırmaya göre, kadınların \%57,1'i dindar, $\% 33,6$ 's1 ortada; erkeklerin ise 66,7'si dindar, \%28,2'si ortada olduğu görülmektedir (Akşit vd, 2012:493). Dini, kültürel ve hayat tarzı kimlikleri tümden, modern dönemde ideolojilerin fonksiyonlarına benzer bir biçimde eylemin anlam ve çerçevesini belirlemektedir. Sosyal kimlikler hayal ürünü de olabilir, ama etkileri hakikidir. Toplumu yorumlamadan ziyade bağımsız bir varlık alanına sahiptirler. $\mathrm{Bu}$ nedenle sosyal kimlikleri bizatihi sosyal dokudan ibaret görebiliriz (Drake, 2016:33).

\section{Siyasi, İdeolojik ve Dini Kimlikler}

Toplumun en yüksek eğitimli grubu olan üniversite öğrencilerinin siyasi-diniideolojik kimlik tercihlerinin önemli ve dikkate alınması gereken bir konu olduğu düşüncesiyle katılımcılara, aşağıdaki siyasi-dini-ideolojik kimlikleri kendinize ne kadar uygun buluyorsunuz? sorusu sorulmuş ve on sekiz siyasi-dini-ideolojik kimlik listesi verilmiştir. Katılımcılardan, bunların her birini kendilerini ne kadar uygun bulupbulmadıklarını, çok uygun-hiç uygun değil arasında dört farklı düzeyde, tercih etmeleri istenmiştir. Alınan cevaplara göre dağılım, Tablo 2'de gösterilmiştir. 


\begin{tabular}{|c|c|c|c|c|c|c|c|c|c|}
\hline Kimlikler & 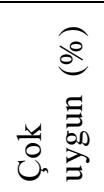 & 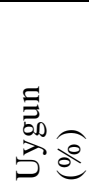 & 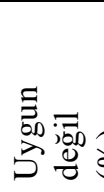 & 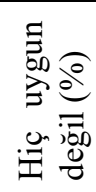 & Kimlikler & $\begin{array}{r}\widehat{o} \\
\stackrel{\Xi}{0} \\
\stackrel{0}{0}\end{array}$ & 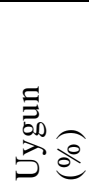 & 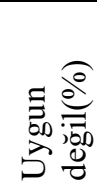 & 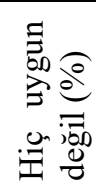 \\
\hline Müslüman & 55,8 & 36,1 & 6,4 & 1,7 & Laik & 32,2 & 48,9 & 10,7 & 8,2 \\
\hline Muhafazakâr & 14,6 & 53,6 & 21,9 & 9,8 & İlerici & 18,5 & 44,6 & 17,6 & 19,3 \\
\hline İslamc1 & 23,6 & 55,8 & 14,6 & 6 & Devrimci & 4,7 & 21,5 & 44,2 & 29,6 \\
\hline Dindar & 20,2 & 52,4 & 18,9 & 8,6 & Sosyalist & 18,5 & 40,3 & 30,9 & 10,3 \\
\hline Demokrat & 26,6 & 55,8 & 14,6 & 3 & Komünist & 3,4 & 9,9 & 37,3 & 49,4 \\
\hline Milliyetçi & 35,2 & 39,5 & 16,7 & 8,6 & Ateist & 2,6 & 3 & 23,2 & 71,2 \\
\hline Kemalist & 13,3 & 24,5 & 40,8 & 21,5 & Feminist & 9,9 & 19,7 & 30,9 & 39,5 \\
\hline Atatürkçü & 27,5 & 41,2 & 21,9 & 9,4 & Liberal & 10,3 & 33,5 & 34,3 & 21,9 \\
\hline $\begin{array}{l}\text { Sosyal } \\
\text { demokrat }\end{array}$ & 15 & 56,2 & 21,5 & 7,3 & Ülkücü & 21,5 & 37,8 & 24,4 & 16,3 \\
\hline
\end{tabular}

Tablo 2: Katılımcıların siyasi-dini-ideolojik kimlikleri

Tablo 2'de verilen siyasi-dini-ideolojik kimlikler, "çok uygun bulunan, uygun bulunan, uygun bulunmayan ve hiç uygun bulunmayan" seçeneklerine göre analiz yapıldığında aşağıdaki sonuçlarla karşılaşılmaktadır: 1.Katılımcıların kendileri için çok uygun buldukları ve benimsedikleri ilk 5 kimlik ve oranı şu şekildedir: Müslüman (\%55,8), Milliyetçi (\%35,2), Laik (\%32,2), Atatürkçü (\%27,5), Demokrat (\%26,6). 2. Katılımcıların kendileri için uygun buldukları ve benimsedikleri ilk 5 kimlik ve oranının şu şekilde olduğu görülmektedir: Sosyal demokrat $(\% 56,2)$, İslamcı ve Demokrat $(55,8)$, Muhafazakâr $(\% 53,6)$, Dindar $(\% 52,4)$, Laik $(\% 48,9)$. 3.Katılımcıların kendileri için uygun bulmadıkları ve benimsemedikleri ilk 5 kimlik ve oranı şu şekildedir: Devrimci $(\% 44,2)$, Kemalist $(\% 40,8)$, Komünist $(\% 37,3)$, Liberal $(\% 34,3)$, Sosyalist ve Feminist (\%30,9). 4.Katılımcıların kendileri için hiç uygun bulmadıkları ve benimsemedikleri ilk 5 kimlik ve oranı ise şu şekildedir: Ateist $(\% 71,2)$, Komünist $(\% 49,4)$, Feminist $(\% 39,5)$, Devrimci $(\% 29,6)$, Liberal $(\% 21,9)$.

İnsan kendi kimliğini tanımlarken kullandığı alternatifler çeşitlidir. Topluluk olma hali ve kültürel pratikler bu noktada belirleyici özellikler taşımaktadır. Böylece kimlik söz konusu olduğunda, bireyin yaptığı ya da yapacağı "öznel” tanımlamalarından çok, dış dünyadan yapılan tanımlamalara dikkat çekmek gerekmektedir. Yani kimliğin 
oluşumu ve bireyin kendini tanımlayabilmesi için "diğer bireylerle simgesel duygu dünyasına ya da sembolik anlam dünyasına girilmesi” gereklidir (Asman 2001:135). Kimlik sorunu, çağlar boyu olduğu gibi günümüzde de hem toplumları, hem de bireyleri ilgilendiren en önemli problemdir. Hiç kuşkusuz, din, mezhep, 1rk, milliyet gibi mukaddes değerler bu kimliklerin belirlenmesinde geçmişte de bugün de çok önemli roller oynamaktadır. Ortaçağda kendilerini din ve mezhep kimlikleriyle tanımlayan toplumlar ve bireyler, endüstri devriminin ortaya çıkmasıyla birlikte bunlara ırk ve milliyet kavramlarını da eklemişlerdir. Toplumlar karmaşıklaştıkça, siyasal tercihler, meslek kimlikleri, cinsiyet bilinci ve yaş grupları da bunlara eklenmiştir. İnsan haklarının gelişmesiyle, din, ırk, milliyet farkı gözetmeden, tüm insanların eşit olduğu anlayışı ortaya çıkmıştır. Böylece gerek toplumlar gerek bireyler, çalışmaları ve başarıları yani insanlığa yaptıkları katkılarıyla değer kazanmaya başlamışlardır (Kongar 2000: 55). Keyman'a (2004: 134) göre, Türkiye'de sosyal demokrasi bugün, ne toplumsal sorunlara çözüm üretmede, ne kendisini farklı toplumsal sinıflar ve kimliklerle eklemlemede, ne de farklı ve demokratik bir Türkiye vizyonu yaratmada başarılı olmaktadır. Bugün Türkiye'de sosyal demokrasinin yaşadığı sorun, hem toplum içinde güvenilirliğinin ve inandırıcılığının azalmasında, hem de sosyal demokrasinin bir ideoloji ve toplumsal hareket olarak farklı toplumsal kesimler içinde sosyal demokrat bir kimlik yaratmaktaki ve toplumla organik bağ kurmaktaki başarısızlığında kendini göstermektedir. Ayrıca bu sorun, bugün Türkiye'de, kendilerini sosyal demokrat olarak tanımlayanların hem nicel hem de nitel anlamda azalması ve giderek marjinalleşmesi anlamina gelmektedir.

\section{Siyaset Algisı}

Araştırmada, üniversite öğrencilerinin siyaset kurumuna ilişkin, düşünce, tutum ve tavırlarını tespit etmek için de bir dizi soruya yer verilmiştir. Bu bağlamda yöneltilen sorulardan birisi, "Genel ve yerel seçimlerde ne sıklıkla oy kullanırsınız?" sorusu olup, $\% 75,1$ 'i her zaman, \%20,2'si bazen, \%4,7'si ise hiçbir zaman cevabını vermiştir. Araştırmanın sonuçları diğer araştırmalarla benzerlik göstermektedir. Yapılan bir 
araştırmaya göre 18-28 yaş grubundaki gençlerde genel ve yerel seçimlerde "her zaman" oy kullanma oran1 \%77 olduğu görülmektedir (KONDA, 2016: 57). TÜSİAD’ın “Seçim Sistemi ve Siyasal Partiler Araştırması'na göre, seçmen kitlesinin siyasete katılım etkinliğinin ilk sırasında 4 puan üzerinden 3,79 ile seçimlerde oy kullanmaktır. Bunu \%3,15 ile medyada siyaset izlemek ve \%1,81 ile siyaset tartışmak takip etmektedir (TÜSİAD, 2001: 14). Türkiye Gençlik Raporu araştırmasına göre de gençlerin \%73,8'i seçimlerde her zaman oy kullandığını ifade etmiştir (SEKAM,2013: 147). Türkiye'de vatandaşların daha çok televizyon izlemek ve gazete okumakla yetinme eğilimde oldukları ve yüksek siyasal etkinlik duygusuna sahip olduklarını belirtmelerine karşın, seçimlerde oy verme dışında her türlü bireysel katılma etkinliğine uzak duran bir kimlik sergiledikleri görülmektedir (Çarkoğlu ve Kalaycığlu, 2018:80). $\mathrm{Bu}$ durum demokratik kültürün gelişmesi, demokratik kurum ve kuralların yerleşmesi açısından önemli bir göstergedir. Seçim, hem düşüncelerin ifadesinin aracı, hem de daha çok bir kural koyma hakkının sembolik ifadesidir. Bu bağlamda demokrasilerde politikayla uğraşmak gerçek gücün diğerleri üzerindeki gerçek konumuna ulaşmayı sağlayacak bir görevlinin seçimde tarafını tutmak demektir. Daha da ötesi seçim, genellikle bireyleri kamusal şahsiyetlere dönüştürmede etkili olan gizemli bir süreç olarak kabul edilir (Herzfeld, 2012:165). Siyasal iktidarın kullanımına katılma hakk1, parlamento ve yerel yönetim meclisleri vatandaşlığın siyasal boyutunu ifade etmektedir. Vatandaşlığın siyasal boyutu, bireyin mensubu olduğu devletle üyeliğini ifade eden resmi bir kimlik niteliğini taşımaktadır (Sarıbay, 1992: 97). Türkiye'de 1945 'te tek parti döneminden (1923-1945) çok-partili demokrasiye geçiş gerçekleşmiştir. Fakat bu başarı, demokrasiyi yerleşikleştirme ve derinleştirme için yeterli olmamıştır. Çünkü demokrasiye geçişte başarılı olan Türkiye, demokrasiyi toplumsal ilişkiler içine, anayasallığa, siyasal kültüre yerleşikleştirmede ve derinleştirmede aynı başarıyı gösterememiştir (Keyman, 2004:136). Türk toplumunda politik katılım, organize toplumun sosyal gruplarının katılımı biçiminde değil; bireysel katılımlar biçiminde gerçekleşmektedir. $\mathrm{Bu}$ durum demokrasinin kökleşmesini ve kurumlaşmasını engellemektedir. Ayrıca, Türk toplumunda demokrasi bir yaşam biçimi ve bir davranış yöntemi olarak benimsenmemiştir. Demokrasinin şekli koşullarının varlığına karşın, 
onun içerik ve niteliğini belirleyen değer, norm ve davranışlar henüz toplum tarafından özümsenmemiştir. Bu yüzden de davranışların demokrat olmasından çok, otoriter ve bağımlı insan tipi yaratan bir biçimde gerçekleştiği görülmektedir (Erkan,1998:212). Ayrıca, demokrasi ekonomik, sosyal ve eğitimsel temellerin desteği olmaksızın kendi ayakları üzerinde duramaz. Geniş bir orta sınıfa, eğitimli yurttaşlara ve düzgün hayat standartlarına sahip olmayan bir toplum bir demokrasi yaratamaz (Karpat, 2017:103). Modern toplumun yeni aktörü bireydir. Birey merkezli yeni toplumsal ilişkiler sistemi orta sinıflar vasıtasıyla sivil topluma, sivil toplum ise demokratik süreçlerin ve örgütlenme düzeylerinin gelişmesiyle birlikte siyasete katılan bir ilişkiler düzeni yaratacaktır. Buradaki birey, toplumsal sorumlulukları, toplumsal duyarlılığı olmayan bencil bir birey değil, toplumsallığını bu yenir çerçevelerde üreten ve değişimin aktörü olarak tarih sahnesinde yeni bir rol alan insandır (Bilgin, 2007:31).

Katılımcıların herhangi bir dernek, vakıf veya STK'ya üyelik durumuna bakıldığında, \%10,7'nin üye, \%17,6'sının gönüllü, \%71,7'sinin ise üye veya gönüllü olmadığı görülmektedir. Türkiye'de yapılan araştırmaya göre, toplumun \%82'si bir STK'ya üye veya gönüllü değildir (KONDA, 2016: 58). Başka bir araştırmaya göre, Türkiye'de toplumsal ve siyasal birliklere, gönüllü kuruluş ve derneklere üye olup onlarda faal olanların ortalaması \% 4-8 arasında bir yerde dururken, hiçbir gönüllü kuruluşa üye olmayanların oranı ise \% 90 civarındadır (Çarkoğlu ve Kalaycığlu, 2018: 85). Görüldüğ̈̈ gibi hem toplumun genelinde hem de gençler arasında STK'lara katılım oranı düşüktür. Bunun bir sebebi de STK'ların gençlere hitap etmemesi veya gençleri hedef kitle olarak almaması veya gençlerin toplumsal katılımları ve taleplerini dile getirebilecekleri platformlar sınırlı olmasıdır. Türkiye'de kurulan derneklerin hedeflediği kitleler itibarıyla gençlere yönelik faaliyet gösteren dernekler \%7,4'e tekabül etmektedir (Onuncu Kalkınma Planı, 2015:21). Sivil toplum kavramı, bazı ahlaki kuvvetlere işaret eder. Çünkü sivil toplum, kamu menfaati için mantıklı bir tartışma içerisine giren, varsayıldığı üzere muhakeme eden ve iyi huylu olan bir toplum ve kamuoyunun kaynağı ile ilişkilidir (Drake, 2016:132-133). Katılımcı demokrasi, demokratik devletin, sivil toplumun örgütsel ve finansal olarak gelişmesine, sivil 
toplum örgütlerinin siyasal, ekonomik ve kültürel aktörlerle ilişkisinin derinleşmesine ve sivil toplum alanının toplumsal yaşamda genişlemesine katkı sağlamasını da içerir (Keyman, 2004:139). Nilüfer Göle’ye (2008:17) göre, 1980 sonrası geleceği yücelten devrimci ütopyalar, piyasa ekonomisinin gelişmesiyle birlikte aşınmaya uğramışlardır. 1970'li yılların devrimci, gelecekteki bir zamana sıçrama yapmak isteyen siyaseti yerini güncel sorunların siyasileşmesine bırakmıştır. Sivil toplumun gelişmesi işte siyasetin gelecekten bugüne, devletten bireye, soyuttan somuta doğru eksen değiştirmesiyle mümkün oldu. Sivil toplumun varlığı, oluşumu ve gücü, toplumsal aktörlerin ve hareketlerin kimliklerini ve söylemlerini nasıl oluşturduklarına ve değişimi nasıl tasavvur ettiklerine bağlıdır. Ancak kendi kendini sınırlayan, yani ötekinin varlığını kabullenen, değişimi, inançları, çıkarları farklı aktörler arası etkileşim, medeniyetler arası aşılanma olarak gören hareketler sivil toplum hareketleridir.

\section{Vatandaşlık İfadesi}

Vatandaşlık sizin için ne ifade ediyor? sorusuna, \%32,6's1 devlete üyelik, \%47,6's1 yasalarda ifade edilen haklar, \%19,7'si yasalarda ifade edilen vazifeler cevabını vermiştir. Bu sonuçlar KONDA'nın araştırması ile benzerlik göstermektedir. Araştırmaya göre, toplumun \%50'si vatandaşlı̆ğ "yasalarda ifade edilen haklar" olarak ifade etmiştir (KONDA, 2016: 7). En genel tanımıyla vatandaşlık, birey-devlet ve birey-birey arasındaki karşılıklı hak ve yükümlülüklere sahip olma durumunu ifade etmektedir. Bu bağlamda, Türkiye'de vatandaşlık anlayışının vatandaşın topluma ve devlete karşı vazifelerine vurgu yaptığı ve modern vatandaşlık anlayışının birey değil, toplum ve devlet temelli bir olgu olarak geliştiği ifade edilebilir. Türkiye'de çok partili hayata geçişle birlikte, adalet dağıtan, koruyan ve denetleyen devletten hukuk devletine geçişin olduğu görülmektedir. Devlet karşısında görev eksenli vatandaş temsili, giderek haklar taşıyıcı vatandaşa ve devletin bu alandaki sorumluluğuna doğru kaymıştır (Üstel 2004: 266). 


\section{Vatandaşılık Tanımı}

\begin{tabular}{|l|l|l|l|l|}
\hline $\begin{array}{l}\text { 1-Kesinlikle katılmıyorum } \begin{array}{l}\text { 2-Katılmıyorum } \\
\text { 3-Katılıyorum }\end{array} \\
\text { 4-Kesinlikle katılıyorum }\end{array}$ & $\begin{array}{l}1 \\
(\%)\end{array}$ & $\begin{array}{l}2 \\
(\%)\end{array}$ & $\begin{array}{l}3 \\
(\%)\end{array}$ & $\begin{array}{l}4 \\
(\%)\end{array}$ \\
\hline $\begin{array}{l}\text { T.C. vatandaş1 olmak için hukuki statü yeterlidir, dil ve din } \\
\text { ortaklı̆̆ı gerekmez. }\end{array}$ & 17,2 & 30,5 & 29,6 & 22,7 \\
\hline T.C .vatandaş1 olmak için Türk ırkından olmak gerekir. & 27,9 & 30,9 & 21,5 & 19,7 \\
\hline T.C. vatandaş1 olmak için Türkçe konuşmak gerekir. & 20,6 & 31,3 & 28,8 & 19,3 \\
\hline Türkçe bilmeyenler T.C. vatandaş1 olmamalıdır. & 26,6 & 30,5 & 27 & 15,9 \\
\hline T.C .vatandaşı olmak için Müslüman olmak gerekir. & 26,6 & 39,1 & 24 & 10,3 \\
\hline
\end{tabular}

Tablo 3: Vatandaş Kimdir? Kim Olmalı, Kim Olmamalı?

Tablo 3'e göre Türkiye Cumhuriyeti vatandaşı olmak için katılımcıların \%52,3'ü hukuki statünün yeterli olduğunu ifade etmiştir. Yine katılımcıların \%58,8'ine göre vatandaşlık için Türk ırkından olmak gerekmemektedir. Yine katılımcıların \%51,9'u vatandaşlık için Türkçe konuşmak gerektiğini, buna karşılık \%48,1'i ise gerekmediğini ifade etmiştir. Ayrıca, katılımcıların \%57,1'i Türkçe bilmeyenin de vatandaş olabileceğini, \%42,9'u ise olamayacağını belirtmektedir. Yine katılımcıların \%65,7'si vatandaş olmak için Müslüman olmak gerekmediğini, buna karşıllk \%34,3’ü ise gerektiğini ifade etmiştir. Sonuç olarak, katılımcılara göre Türkiye Cumhuriyeti vatandaşı olmak için hukuki statü yeterlidir. Bunun dışında kişinin Türkçe konuşmaması veya bilmemesi, Müslüman veya Türk ırkından olmaması vatandaş olmasına engel olmamaktadır. Yine, katılımcıların vatandaşlığı daha çok hukuki bir statü veya durum olarak gördükleri anlaşılmaktadır.

\section{Vatandaşlık: Haklar, Görevler ve Sınırlar}

Tablo 4'e göre katılımcıların \%71,2'si devlete karşı sorumluluklarımız haklarımızdan önce gelir, \%62,6's1 vergi vermeyenlerin temel vatandaşlık hakları olmamalıdır, \%49,7'si askerlik yapmayanların temel vatandaşlık hakları olmamalı, \%58,8'i devlete karşı vatandaşlık görevlerini yerine getirmeyenlerin sağlık ve eğitim hizmeti almalarına karşıyım, \%88,4'ü devlet, vatandaşlarını tercihlerinden ötürü maruz 
kalabilecekleri ayrımcılığa ve saldırılara karşı korumakla yükümlüdür ifadelerine katıldıklarını ifade etmişlerdir. Demokratik ve toplumsal modernleşmeye katkıda bulunan devlet, hem devlet-toplum/birey ilişkilerini hem de toplumsal kesimler arası ilişkileri, haklar ve sorumluluklar ilkeleri temelinde düzenleyen devlettir (Keyman,2004:139). Giddens'a göre (2000:114), demokratik devletin özgül rolü bireyi kendine tabi kılmak değil, aksine onun kendi kendini gerçekleştirmesine imkân hazırlamaktır. Bireyin kendi kendini gerçekleştirmesi, ancak devletin ahlaki bireycilikte cisimleşmiş olan hakları garanti altına alıp geliştirdiği bir toplum içinde ve o toplumun mensubu olması sayesinde mümkün olabilir.

\begin{tabular}{|l|l|l|l|l|}
\hline $\begin{array}{l}\text { 1-Kesinlikle katılmıyorum } \\
\text { 3-Katılıyorum } \\
\text { 2-Katılmısorum }\end{array}$ & $\begin{array}{l}1 \\
(\%)\end{array}$ & $\begin{array}{l}2 \\
(\%)\end{array}$ & $\begin{array}{l}3 \\
(\%)\end{array}$ & $\begin{array}{l}4 \\
(\%)\end{array}$ \\
\hline Devlete karşı sorumluluklarımız haklarımızdan önce gelir. & 9,4 & 19,3 & 44,2 & 27 \\
\hline Vergi vermeyenlerin temel vatandaşlık hakları olmamalıdır. & 11,2 & 26,2 & 35,6 & 27 \\
\hline Askerlik yapmayanların temel vatandaşlık hakları olmamalı. & 15,9 & 34,3 & 30 & 19,7 \\
\hline $\begin{array}{l}\text { Devlete karşı vatandaşlık görevlerini yerine getirmeyenlerin } \\
\text { sağlık ve eğitim hizmeti almalarına karşıyım. }\end{array}$ & 14,2 & 27,1 & 35,6 & 23,2 \\
\hline $\begin{array}{l}\text { Devlet, vatandaşlarını tercihlerinden ötürü maruz kalabilecekleri } \\
\text { ayrımcılığa ve saldırılara karşı korumakla yükümlüdür. }\end{array}$ & 5,6 & 6 & 46,8 & 41,6 \\
\hline
\end{tabular}

Tablo 4: Katılımcıların Vatandaşlık Anlayışı

\section{Eşit Vatandaşlık ve Farklııklara Bakış}

\begin{tabular}{|l|l|l|l|l|}
\hline $\begin{array}{l}\text { 1-Kesinlikle katılmıorum 2-Katılmıyorum } \\
\text { 3-Katılıyorum 4- Kesinlikle katılıyorum }\end{array}$ & $\begin{array}{l}1 \\
(\%)\end{array}$ & $\begin{array}{l}2 \\
(\%)\end{array}$ & $\begin{array}{l}3 \\
(\%)\end{array}$ & $\begin{array}{l}4 \%) \\
(\%)\end{array}$ \\
\hline $\begin{array}{l}\text { Türkiye'nin Müslüman olmayan vatandaşları Cumhurbaşkanı } \\
\text { olabilmelidir. }\end{array}$ & 33,5 & 31,3 & 24 & 11,2 \\
\hline $\begin{array}{l}\text { Devlet camiler dışındaki ibadet yerlerine de kaynak } \\
\text { sağlamalıdır. }\end{array}$ & 6 & 11,6 & 48,1 & 34,3 \\
\hline $\begin{array}{l}\text { Öğretmen, hâkim gibi tüm kamu çalışanları da dâhil olmak } \\
\text { üzere örtünmek isteyen örtünebilmelidir. }\end{array}$ & 7,3 & 10,3 & 23,2 & 59,2 \\
\hline $\begin{array}{l}\text { İşyerlerinde tüm çalışanların dinlerini kapsayan ibadet yerleri } \\
\text { olmalıdır. }\end{array}$ & 3 & 6,7 & 60,9 & 28,3 \\
\hline $\begin{array}{l}\text { İşyerlerinde mescit olmalıdır. } \\
\text { Farklı cinsel yönelime sahip vatandaşların devletin eğitim ve } \\
\text { sağlık hizmetlerinden yararlanmasına karşıım. }\end{array}$ & 31,8 & 31,8 & 24,9 & 11,6 \\
\hline
\end{tabular}

Tablo 5: Katılımcıların Eşit Vatandaşlık ve Farklılıklara Nasıl Baktığı 
Tablo 5'e göre katılımcıların \%64,8 gibi bir oranı Müslüman olmayanın Türkiye’nin Cumhurbaşkanı olmasını istememektedir. Ayrıca, katılımcıların \%82,4 gibi yüksek bir oranı devletin cami dışındaki ibadet yerlerine de kaynak aktarmasını ve örtünmek isteyen tüm kamu personelinin örtünebilmesi gerektiğini ifade etmiştir. Katılımcıların farklılıklara nasıl baktıkları incelendiğinde ise, hem işyerlerinde tüm çalışanları kapsayan ibadet yerleri olmasını $(\% 89,9)$ hem de işyerlerinde mescit olmasını (\%88) çok yüksek oranda kabul ettikleri görülmektedir. Yine, katılımcıların büyük bir oranının $(\% 63,6)$ farklı cinsel yönelime sahip vatandaşların devletin eğitim ve sağlık hizmetlerinden yararlanmasına karşı olmadığı görülmekteyken \%36,5 gibi azımsanmayacak bir oranın buna karşı olması dikkat çekici bir durumdur. Yine bu bağlamda katılımcılara, Farklı mezhepten/farklı dinden/farklı etnik kökenden biriyle evlenir misiniz? sorusu sorulmuş \%54,1 evet, \%45,9 hayır cevabını vermiştir. Kızımın veya oğlumun farklı cinsel tercihleri olmasını ister misiniz? sorusuna ise \%75,6 istemem, \%24,5 isterim cevabını vermiştir.

Sizce Türkiye'nin en önemli sorunu nedir? sorusuna katılımcıların \%9'u yolsuzluk, \%34,3'ü terör, \%9,9'u ahlaki yozlaşma, \%1,3'ü yoksulluk, \%0,9'u irtica, \%20,2'si eğitim, \%20,6'sı adaletsizlik, \%3,9'u düşünce özgürlüğü cevabını vermiştir. Buna göre öne çıkan ilk üç sorun sırasıyla; terör, adaletsizlik ve eğitimdir. Bu sonuç yapılan diğer araştırmalarla benzerlik göstermektedir. Kadir Has Üniversitesi Türkiye Çalışmaları Merkezi tarafından yapılan "Türkiye Sosyal-Siyasal Eğilimler Araştırması'nda" da Türkiye'nin en önemli sorunu \%29 ile terördür (Aydın vd, 2018: 15). Ayrıca, katılımcılar için irtica Türkiye için öncelikli bir sorun değildir. Terörün ilk sırada gelmesi diğer araştırmalarla benzerlik göstermektedir. Modern ulus devletlerin kuruldukları topraklar üzerinde yaşayan halka sağladığı güvence ve hizmetler bulunmaktadır. Bunların en başında da güvenlik gelmektedir. Toplumun iç ve dış tehditlere karşı korunması modern devletlerin en önemli görevidir. 


\section{Sonuç}

$\mathrm{Bu}$ araştırmada üniversite öğrencilerinin kimlik ve siyaset algıları ele alınmıştır. Toplumun en eğitimli ve en dinamik insan gücü olan üniversite gençliğinin bir kimlik sorunu yaşadığı görülmektedir. Araştırmada bu bağlamda, diğer araştırmalarla benzer sonuçlar elde edilmiştir. Araştırmanın sonuçlarından birisi şudur: Katılımcıların yüksek bir oranı $(\% 89,5)$, modern-gelenek düzleminde, kendilerini biraz modern biraz geleneksel olarak görmektedir. Araştırmanın başka bir sonucu; katılımcıların önemsedikleri ve önceledikleri üç toplumsal aidiyetin/kimliğin Müslüman gibi dini, T.C. vatandaşı gibi siyasi ve Türk gibi etnik/siyasi aidiyetler olduğudur. Ayrıca, katılımcıların siyasi-dini-ideolojik düzleminde kendilerine çok uygun bulduklarıl benimsedikleri kimliklerin ilk üçü sırasıyla, Müslüman, Milliyetçi, Laik; uygun buldukları ise Sosyal demokrat, İslamcı ve Demokrat, Muhafazakârdır. Yine katılımcıların kendileri için uygun bulmadıkları ve benimsemedikleri ilk üç kimlik sırayla Devrimci, Kemalist ve Komünisttir. Katılımcıların kendileri için hiç uygun bulmadıkları ve benimsemedikleri ilk üç kimlik ise sırasıyla Ateist, Komünist ve Feministtir.

Araştırmanın bir başka sonucuna göre; gençlerin siyasete katılmalarının daha çok seçimlerde oy verme şeklinde olduğu görülmektedir. Ayrıca, gençlerin sivil toplum örgütlerine katılım düzeyi çok düşüktür. Bu iki sonuç yapılan araştırmalarla ve Türk halkının genel eğilimi ile paralellik göstermektedir. Katılımcılara göre, Türkiye Cumhuriyeti vatandaşı olmak için hukuki statü yeterlidir. Bunun dışında kişinin Türkçe konuşmaması veya bilmemesi, Müslüman veya Türk 1rkından olmaması, vatandaş olmasına engel değildir. Yine, katılımcıların vatandaşlı̆ğ daha çok hukuki bir statü veya durum olarak gördükleri anlaşılmaktadır. Katılımcıların vatandaşlık anlayışları ise şöyledir: Katılımcıların \%88,4'ü devlet, vatandaşlarını tercihlerinden ötürü maruz kalabilecekleri ayrımcılığa ve saldırılara karşı korumakla yükümlüdür, \%71,2'si devlete karşı sorumluluklarımız haklarımızdan önce gelir, \%62,6's1 vergi vermeyenlerin temel vatandaşlık hakları olmamalıdır şeklindedir. 
Araştırmanın bir başka sonucu şudur: Katılımcılara göre bir kişinin Türkiye'nin Cumhurbaşkanı olması için Müslüman olması gerekmektedir. Ayrıca, devletin cami dışındaki ibadet yerlerine de kaynak aktarmasını ve örtünmek isteyen tüm kamu personelinin örtünebilmesi gerektiğgini ifade etmiştir. Katılımcıların farklılıklara nasıl baktıkları incelendiğinde ise, hem işyerlerinde tüm çalışanları kapsayan ibadet yerleri olmasını $(\% 89,9)$ hem de işyerlerinde mescit olmasını $(\% 88)$ çok yüksek oranda kabul ettikleri görülmektedir. Yine, katılımcıların büyük bir oranının $(\% 63,6)$ farklı cinsel yönelime sahip vatandaşların devletin eğitim ve sağlık hizmetlerinden yararlanmasına karşı olmadığı görülmektedir. Yine bu bağlamda, katılımcıların yarıdan fazlası $(\% 54,1)$ farklı mezhepten/farklı dinden/farklı etnik kökenden biriyle evlenebileceğini ifade etmiştir. Ancak, yüksek bir oran $(\% 75,6)$ kızımın veya oğlumun farklı cinsel tercihleri olmasını istememektedir. Araştırmanın bir başka sonucu şudur: Katılımcılara göre Türkiye'nin en önemli sorunları arasında öne çıkan ilk üç sorun sırasıyla; terör, adaletsizlik ve eğitimdir.Bu sonuç yapılan diğer araştırmalarla benzerlik göstermektedir.

Üniversite öğrencilerinin kimlik ve siyaset algılarını tespit etmeye yönelik olan bu araştırmada özellikle gençlerin bir kimlik bunalımı içinde oldukları ve seçimlerde oy kullanmak dışında başka bir siyasi katılım faaliyeti içinde olmadığı görülmektedir. Toplumun en eğitimli ve aydın kesimi olan üniversite öğrencilerinin bir kimlik bunalımı içinde olması dikkate alınması gereken bir durumdur. Özellikle kamu otoritesinin, ailelerin ve STK'ların bu durum üzerine daha fazla eğilmeleri gerekmektedir. Yapılan araştırmalarda, gençlere hitap eden STK'ların yeterli sayıda olmadığı görülmektedir. Bu sorunun çözülmesi gerekmektedir. Gençler, bir toplumun geleceğidir. Gençlere yapılan yatırım, hepimizin geleceğine yapılan yatırımdır. 


\section{KAYNAKÇA}

AKŞIT, Bahattin; ŞENTÜRK, Recep; KÜÇÜKURAL, Önder; CENGIZZ, Kurtuluş (2012). Türkiye'de Dindarlık, İstanbul: İletişim Yayınları. Yay.

ASSMANN, Jan (2001), Kültürel Bellek, çev. Ayşe Tekin, İstanbul, Ayrıntı

AYDIN, Mustafa; KAHRAMAN, H.Bülent; BAYBARS HAWKS, Banu; ZAİM, Osman Z.; DİZDAROĞLU, Cihan (2018). Türkiye Sosyal-Siyasal Eğilimler Araştırması, İstanbul: Kadir Has Üniversitesi Türkiye Çalışmaları Merkezi Yayınları.

BAYART, Jean-François (1999). Kimlik Yanılsaması, çev. Mehmet Moralı, İstanbul: Metis Yayınları. Yayınlar1.

BERKES, Niyazi (2016). Türk Düşününde Batı Sorunu, İstanbul: Yapı Kredi

BİLGIN, Nuri (2007). Kimlik İnşası, Ankara: Aşina Kitaplar. Yayınevi.

BİLGİN, Vedat (2007). Türkiye'de Değişimin Dinamikleri, Ankara: Lotus

ÇARKOĞLU, Ali ve KALAYCIOĞLU, Ersin (2018). Türkiye'de ve Dünya'da Vatandaşlık, Koç Üniversitesi İstanbul Politikalar Merkezi Yayınları.

DRAKE, Michael S. (2016). Siyaset Sosyolojisi, çev. Hüsamettin İnaç, İstanbul:Bilge Kültür Sanat Yayınları.

ERKAL, Mustafa E.; Burhan ve Filiz BALOĞLU (1997). Ansiklopedik Sosyoloji Sözlüğ̈̈, İstanbul: Der Yayınları.

ERKAN, Hüsnü (1998). Bilgi Toplumu ve Ekonomik Gelişme, İstanbul: İş Bankası Yayınları.

GIDDENS, Anthony (2000).Siyaset, Sosyoloji ve Toplumsal Teori, İstanbul: Metis Yay.

GÖLE, Nilüfer (2008). Mühendisler ve İdeoloji, İstanbul: Metis Yayınları.

HERZFELD, Michael (2012). Antropoloji: Kültürde ve Toplumda Teorik Uygulama, çev. Bülent Toksöz, İstanbul: Say Yayınları.

İNALCIK, Halil (2017). Türklük Müslümanlı ve Osmanlı Mirası, İstanbul:Kırmızı Yay.

KALKINMA BAKANLIĞI (2015). Onuncu Kalkınma Planı: Gençlik Çalışma Grubu Raporu, Ankara: Kalkınma Bakanlığı Yayınları.

KARA, İsmail (2010). Cumhuriyet Türkiyesi'nde Bir Mesele Olarak Isslam, İstanbul: Dergah Yay.

KARPAT, Kemal H. (2009). Osmanlı'dan Günümüze Elitler ve Din, çev. Güneş Ayas, İstanbul: Timaş Yayınları. 
KARPAT, Kemal H. (2017). Osmanlı'dan Günümüze Kimlik ve İdeoloji, çev. Güneş Ayas, İstanbul: Timaş Yayınları.

KEYMAN, E. Fuat (2009). "Sistem Kurucu ve Sistem Dönüştürücü Bir Toplumsal Gerçeklik Olarak Kültürel Kimlik Olgusunu Yeniden Düşünmek”, Kimlikler Lütfen, Türkiye Cumhuriyeti'nde Kültürel Kimlik Arayışı ve Temsili, Derleyen:Gönül Pultar, ss. 50-59, Ankara: ODTÜ Yayınları.

KEYMAN, Fuat (2004). "Sosyal Demokrasi ve Türkiye”, İdeolojiler, Doğu Batı Düşünce Dergisi, 29(2):123-143.

KONDA (2016). Vatandaşl1k Araştırmas1, http://konda.com.tr/wpcontent/uploads/ 2017/03/ VatandaslikArastirmasiRapor.pdf, Erişim Tarihi:02.02. 2018.

KONGAR, Emre (2000). 28 Şubat ve Demokrasi, İstanbul: Remzi Kitabevi. Yayınları.

MARDİN, Şerif (2017). Türkiye, Isslam ve Sekülarizm. İstanbul: İletişim Yayınları.

MARDİN, Şerif (2017). Türkiye, İslam ve Sekülarizm. İstanbul: İletişim

MORLEY, David ve KEVIN Robins (1997). Kimlik Mekanlart. çev. Emrehan Zeybekoğlu, İstanbul: Ayrıntı Yayınları.

ORTAYLI, İlber (2006). Osmanlı Barışı. İstanbul: Ufuk Kitap.

SARIBAY, Ali Yaşar (1992). Siyasal Sosyoloji, Ankara: Gündoğan Yayınları.

SEKAM (2016). Üniversite Öğrencilerinin Hayat Tarzl ve Toplumsal Değerler, İstanbul: Sosyal, Ekonomik ve Kültürel Araştırmalar Merkezi Yayınları.

TOPSES, Mehmet Devrim (2017). “18. Yüzyıl Sonrası Türk Modernleşmesinin Sinıfsal Temelleri”, Ulakbilge Sosyal Bilimler Dergisi, (5)17, s. 1857-1874. 2016.

TÜRKIYE İSTATISTIK KURUMU [TÜIKK] (2017a). İstatistiklerle Kadın

TÜRKIYE İSTATISTIKK KURUMU [TÜİK] (2017b). İstatistiklerle Gençlik 2016.

TÜSİAD (2001). Seçin Sistemi ve Siyasi Partiler Araştırması, İstanbul: TÜSİAD Yayınları.

ÜSTEL, Füsun (2004). Makbul Vatandaşın Peşinde, İstanbul: İletişim Yayınları. 